\title{
A Mixed Analysis on the Study Habits of Middle School Students
}

\author{
Salih USLU ${ }^{1} \&$ Melek KÖRÜKCÜ ${ }^{1}$ \\ ${ }^{1}$ Faculty of Education, Nigde Ömer Halisdemir University, Nigde, Turkey \\ Correspondence: Melek KÖRÜKCÜ, Nigde Ömer Halisdemir University Faculty of Education, F:2 NO:211 \\ Nigde, Turkey. E-mail: melekkorukcu@ohu.edu.tr
}

Received: February 22, 2021 Accepted: April 22, 2021 Online Published: May 14, 2021

doi:10.5539/jel.v10n3p140 URL: https://doi.org/10.5539/jel.v10n3p140

\begin{abstract}
This study investigated middle school students' thoughts and attitudes towards study habits. The study employed an explanatory sequential design, which is a mixed method. The research consisted of two stages: quantitative and qualitative. The quantitative sample consisted of 205 students (116 girls and 89 boys) of a public middle school in the center of a city in the Central Anatolia Region in the 2019-2020 academic year. For the qualitative stage, fifteen students (seven girls and eight boys) were recruited from the quantitative sample using maximum variation sampling. The quantitative data were collected using the Questionnaire for Study Habits developed by Yenilmez and Özbey. Participants were interviewed using a semi-structured interview form consisting of open-ended questions. The quantitative data were analyzed using the Statistical Package for Social Sciences (SPSS v. 24.0). The results showed that participants had a moderate level of study habits. Gender and grade level were not correlated with study habits. Participants with appropriate study space had better study habits. Participants associated study habits with success in the future. The results showed that the Internet, tablet, and TV had adverse impacts on study habits and positive or negative effects on parents and teachers.
\end{abstract}

Keywords: study habits, middle school students, studying

\section{Introduction}

"What will humans be like in the future?" is a question we have been asking ourselves since the beginning of time. We have always sought knowledge and strived to make sense of it to build the future. An individual has the potential to perceive and turn things into reality and energy to achieve that potential (Aristoteles, 2000). She uses her thinking abilities to actualize that energy. In this way, she can make meaningful connections and access knowledge. "Go forth now and question. Ask and listen. The world is just beginning to open up to you. Each person you question can take you to a new part of the world. The skilled questioner and attentive listener how to enter into another's experience. If you ask and listen, the world will always be new." (Patton, 2016, p. 340). As stated by Patton, the world is still new to us. This new world is called the 4.0 industrial era. All aspects of life (economy, education, management, production, culture, technology, etc.) are undergoing a dramatic transformation. The pillar of strength in this new era is building the future by researching, accessing information, learning, and putting what you learn into practice. The protagonist of this transformation is the individual. In order to build a meritocratic structure, the education system should turn students into well-equipped and competent individuals with 21 st-century skills and values (Fullan, 2007, pp. 8-9).

Success and failure as a potential depend on whether the individual manages to complete her duties and responsibilities (Dreeben, 2010, p. 143). Effective learning is the key to success. Information should be tailored to the individual and used actively together with other information. To that end, the individual should acquire study habits. It takes more than just knowing and keeping information in mind to reach goals (Dural, 2008).

Study habits are defined as techniques and methods used to manage the learning process (Bayır, 2015). Study habits developed at an early age affect lifelong success. Habits are not innate but acquired. The individual who can set their priorities and put them into practice to reach goals are more likely to develop study habits (Tan, 1996; Yeşilyaprak, 2019). This process is affected by personality traits, the environment, and educators' characteristics (Eren, 2011; Özcan, 2006; Özsoy, Memiş, \& Temur, 2009). These factors also affect student engagement, effective reading, note-taking, finishing assignments and tasks on time, preparing for exams, and academic success, which are all related to study habits (Uluğ, 2012; Yıldırım, Doğanay, \& Türkoğlu, 2000; Gettinger \& Seibert, 2002; Yeşilyaprak, 2019) because study habits, or a lack thereof, are what put the individual 
on the right or wrong path (Loeserman \& Verdaguer, 2004, p. 75).

In order to develop or break study habits, the student should first receive stimuli that activate those habits, switching her brain to automatic mode. Then she settles into a routine based on her physical, mental, and emotional predispositions. In the last stage, she rewards herself after she decides whether it is worth repeating that cycle or not. In this process, she should assume responsibility for her success or failure. Bad study habits are not unique to unsuccessful students. Some bad study habits have to do with time management issues, inappropriate study space, and using resources, facilities, tools, and materials for purposes other than learning (Avc1, 2006, p. 4; Türkoğlu, Çengel, \& Yılmaz, 2006). For effective study, the student should know herself and the learning styles that best fit her and turn them into a habit. She should break the study habits that stonewall the learning outcomes she hopes to achieve (Durmuss, 2005). This study focused on middle school students' study habits and their views of them. The objective was to raise their awareness of the issue.

\section{Research Objective}

This study investigated middle school students' attitudes towards their study habits. To that end, it sought answers to the following questions:

1) What level of study habits do middle school students have?

2) Is there a difference in study habits between male and female middle school students?

3) Do middle school students who have appropriate study space have better study habits than those who do not?

4) Do study habits differ by grade level?

5) What does "study habits" mean to middle school students?

6) What kind of role do parents play in the acquisition of study habits?

7) What kind of role do teachers play in the acquisition of study habits?

8) What factors affect middle school students' study habits?

\section{Method}

This mixed design study employed both qualitative and quantitative methods. Mixed design studies adopt at least two different research models and check whether qualitative results corroborate quantitative ones, extending the scope of the analysis and interpretation of the research problem (Tashakkori \& Creswell, 2007). The convergent parallel design involves the researcher applying quantitative and qualitative designs at one stage. At the last stage, the researcher synthesizes the quantitative and qualitative results in accordance with the design. The quantitative part of the research was designed according to the general scanning model, one of the scanning models. In this model, the aim is to make a general judgment about the universe. In the qualitative part of the research, it was designed according to the case study. Descriptive case study design is used. This pattern answers why and how questions about a situation (Karasar, 2012).

\subsection{Participants}

The quantitative sample consisted of 205 students (116 girls and 89 boys) of a public middle school in the center of a city in the Central Anatolia Region in the 2019-2020 academic year. For the qualitative stage, fifteen students (seven girls and eight boys) were recruited from the quantitative sample using maximum variation sampling, through which a sample with a broad spectrum of positions and perspectives is drawn from the population (Karasar, 2012).

\subsection{Data Collection Tools}

The quantitative data were collected using the Questionnaire for Study Habits (QSH) developed by Yenilmez and Özbey (2007). In this study, the total questionnaire had a Cronbach's Alpha $(\alpha)$ of .96. The questionnaire consists of 12 parts: active learning $(\alpha=.84)$, time management $(\alpha=.73)$, preparing to study $(\alpha=.83)$, taking notes during class $(\alpha=.81)$, reading textbooks $(\alpha=.78)$, marking and taking notes on the text $(\alpha=.81)$, word and concept development $(\alpha=.79)$, memory $(\alpha=.79)$, doing tests $(\alpha=.75)$, motivation $(\alpha=.73)$, human, resources, and rest $(\alpha=.68)$, and stress and anxiety while doing homework assignments $(\alpha=.76)$

Participants were interviewed to determine the factors affecting their study habits. The objective of the interview method is to elicit the same type of information on a similar topic from different individuals. An interview form should include questions and topics of interest (Patton, 2016). The interviews were conducted using a semi-structured questionnaire form consisting of four open-ended questions addressing students' personality traits and study habits. The form was developed based on the feedback of three academics. 


\subsection{Data Analysis}

The data were analyzed using the Statistical Package for Social Sciences (SPSS, IBM, version 24.0) at a significance level of 0.05. An independent samples t-test was used to determine whether participants' QSH scores differed by gender and appropriate study space. An independent samples one-way analysis of variance (ANOVA) was used to determine whether participants' QSH scores differed by grade level. The qualitative data were analyzed using inductive content analysis, making inferences from qualitative data and reducing it to key attributes. To that end, similar data are classified into themes and concepts and then interpreted (Patton, 2016). The attributive units derived from participants' responses were converted into themes, categories, and codes. The "Results" section addressed them in detail. Participants were assigned codes (P1, P2 ... P15) to protect anonymity.

\section{Results}

\subsection{Results of the First Research Question}

This section sought answers to the first question, "What level of study habits do middle school students have?" Table 1 shows the results.

Table 1. Level of study habits: QSH scores

\begin{tabular}{llll}
\hline Factors & $\overline{\mathrm{X}}$ & $\mathrm{Ss}$ & Level \\
\hline Active learning & 3.40 & 10.04 & Sometimes (Moderate) \\
Time management & 3.18 & 5.95 & Sometimes (Moderate) \\
Preparing to study & 3.42 & 9.36 & Often (High) \\
Taking notes during class & 3.71 & 5.07 & Often (High) \\
Reading textbooks & 3.33 & 8.70 & Sometimes (Moderate) \\
Marking and taking notes on the text & 2.02 & 5.16 & Rarely (low) \\
Word and concept development & 3.42 & 4.04 & Often (High) \\
Memory & 3.54 & 4.25 & Often (High) \\
Doing tests & 3.36 & 6.11 & Sometimes (Moderate) \\
Motivation & 3.37 & 6.87 & Sometimes (Moderate) \\
Human, resources, and rest & 3.16 & 4.50 & Sometimes (Moderate) \\
Stress and anxiety while doing homework assignments & 2.51 & 4.24 & Rarely (low) \\
Total & 3.34 & 54.59 & Sometimes (Moderate) \\
\hline
\end{tabular}

The results showed that participants had a moderate level of study habits. They were mostly in the habit of taking notes during class, followed by memorizing, preparing to study, learning words and concepts, learning actively, motivating themselves, doing tests, reading textbooks, managing time, turning to other people and resources for assistance, and resting, feeling stress and anxiety while doing homework assignments, and marking and taking notes on the text. This result indicated that participants were mostly in the habit of taking notes during class, memorizing, preparing to study, learning words and concepts, whereas they were in the habit of marking and taking notes on the text and feeling stress and anxiety while doing homework assignments the least (Table $1)$.

\subsection{Results of the Second Research Question}

This section addressed the second research question, "Is there a difference in study habits between male and female middle school students?" An independent sample t-test was used to answer the question. Table 2 shows the results.

Table 2. Distribution of QSH scores by gender

\begin{tabular}{llllllll}
\hline Study Habits & Gender & $\mathbf{n}$ & $\bar{X}$ & Ss & sd & t & p \\
\hline Total & Girl & 116 & 3.41 & .62 & 203 & 1.792 & .75 \\
& Boy & 89 & 3.25 & .62 & & & \\
\hline
\end{tabular}

There was no significant difference in study habits between male and female participants $\left(\mathrm{t}_{(203)}=1.792 ; \mathrm{p}>.05\right)$, suggesting that gender did not affect study habits (Table 2). 


\subsection{Results of the Third Research Question}

The third question investigated whether participants who had appropriate study space had more study habits than those who did not. Table 3 shows the results.

Table 3. Distribution of QSH scores and T-test results by appropriate study space

\begin{tabular}{llllllll}
\hline Study Habits & Appropriate Study space & $\mathbf{n}$ & $\overline{\mathrm{X}}$ & Ss & sd & $\mathbf{t}$ & $\mathbf{p}$ \\
\hline Total & Yes & 176 & 3.39 & .61 & 203 & 2.813 & $.008^{*}$ \\
& No & 29 & 3.02 & .66 & & & \\
\hline
\end{tabular}

There was a significant difference in study habits between participants with and without appropriate study space $\left(\mathrm{t}_{(203)}=2.813 ; \mathrm{p}<.05\right)$, indicating that participants who had appropriate study space had better study habits than those who did not (Table 3 ).

\subsection{Results of the Fourth Research Question}

The fourth question looked into the effect of grade level on study habits. Table 4 shows the results.

Table 4. Effect of grade level on study habits: One-way Anova results

\begin{tabular}{|c|c|c|c|c|c|c|c|c|c|c|}
\hline Factor & Grade level & $\mathrm{n}$ & $\overline{\mathrm{x}}$ & Ss & VK & KT & sd & KO & $\mathbf{F}$ & $\mathbf{p}$ \\
\hline \multirow[t]{4}{*}{ Total } & 6 & 138 & 3.30 & .64 & Between-group & 6255.721 & 2 & 3127.861 & 1.050 & .352 \\
\hline & 7 & 38 & 3.43 & .65 & Within-group & 601656.357 & 202 & 2978.497 & & \\
\hline & 8 & 29 & 3.43 & .54 & Total & 607912.078 & 204 & & & \\
\hline & Total & & 3.34 & .63 & & & & & & \\
\hline
\end{tabular}

Note. ${ }^{*} \mathrm{p}<.05$.

The results indicated no significant effect of grade level on study habits $\left(\mathrm{F}_{(2-202)}=1.050, \mathrm{p}>.05\right)$, suggesting that study habits did not differ across grade levels (Table 4).

\subsection{Results of the Fifth Research Question}

The first question focused on what "study habits" meant to participants. Table 5 presents the related themes and categories.

Table 5 . The meaning of study habits to participants

\begin{tabular}{llll}
\hline Themes & Categories & Content Codes & $\mathrm{f}$ \\
\hline Self-efficacy & Success & Helping become successful, helping measure & 5 \\
& Need & Necessary to succeed in life & 3 \\
& Perseverance & Helping become more motivated to study, obliging parents & 4 \\
Plan & Sustainability & Requiring sustainability, a long process, more challenging when interrupted & 3 \\
& Orderliness & Everything getting mixed up when disorganized A task that needs to be completed as a reality of & 4 \\
& Routine & life, necessary, like bread and water & 4 \\
Motivation & Precondition & The only precondition to succeed in exams & 5 \\
& Future & Necessary to attend a good high school and university, something that parents want & 6 \\
& Career & Needed to have a good job, high grades & 4 \\
\hline
\end{tabular}

The concepts that participants associated study habits with were success $(n=5)$, need $(n=3)$, and perseverance $(\mathrm{n}=4)$ under the category of "self-efficacy;" sustainability $(\mathrm{n}=3)$, orderliness $(\mathrm{n}=4)$, and routine $(\mathrm{n}=4)$ under the category of "plan;" precondition $(n=5)$, future $(n=6)$, and career $(n=4)$ under the category of "motivation." Some quotes from participants are as follows: P11 "Study habits are a must in certain times, especially in exam years. The more you study, the more you want to study, you feel bad if you don't. Besides, you become more and more successful if you study whenever you feel bored." P8 "Having study habits means being a bright student." P5 "To me, study habits mean continuous gain because the more you study, the more you gain. Besides, the key to success is sustainability. It's harder to stay on top than it is to make the climb."

\subsection{Results of the Sixth Research Question}

The sixth question examined what role parents played in study habits. Table 6 presents the related themes and 
categories.

Table 6. Parents' role in study habits

\begin{tabular}{llll}
\hline Themes & Categories & Content Codes & 6 \\
\hline Positive & Support & Financial support, nice words & 5 \\
& Helpful & Solving questions together, making up for shortcomings, keeping things under control & 3 \\
& Example & Parents working regularly & 6 \\
Negative & Reminding & Parents constantly "nagging" and reminding us to study & 4 \\
& Pressure & Extreme attitudes, not letting us play, Not asking what we want, suffocating us & \\
\hline
\end{tabular}

Parental effect on study habits was grouped under the themes of "positive" and "negative." Under the theme of "positive," six participants stated that their parents provided for them and said nice words to them. Five participants noted that their parents kept things under control and helped them with their study and shortcomings. Three participants remarked that their parents set an example for them because they were hard-working people. Under the theme of "negative," six participants complained about their parents constantly "nagging" them to study, while four participants noted that their parents pressured them into studying. Some quotes from participants are as follows: P1 "Constant reminders and warnings have helped me develop study habits. Both my parents' and my brother's warnings really paid off." P18 "My parents are always pressuring me into studying. I say, 'I don't want to,' but they shut the door on me. I mean, they shouldn't make me study, but they just don't get it." P15 "My mom helped me a lot to do well in the entrance exam. My dad kept it as quiet as possible at home, but my siblings had some negative effects. Silence is vital while studying at home. Personal space is also very important, but more siblings mean less personal space."

\subsection{Results of the Seventh Research Question}

The seventh question addressed what role teachers played in study habits. Table 7 presents the related themes and categories.

Table 7. Teachers' role in study habits

\begin{tabular}{llll}
\hline Theme & Category & & \\
\hline Positive & Listening & Answering questions about assignments and lessons clearly & 3 \\
& Support & helping build self-confidence, warning about mistakes, referring to guidance service, & 5 \\
& & reducing anxiety and stress, guiding, treating fairly & 4 \\
Negative & Question-Answer & Leaving questions unanswered, saying, 'No' & 2 \\
& Lesson & Giving too much homework, not associating subjects with each other, not doing & 2 \\
& & homework follow-up & \\
\hline
\end{tabular}

Under the theme of "positive," participants stated that their teachers supported $(n=5)$ and helped them $(n=4)$. Under the theme of "negative," they noted that teachers left their questions unanswered, gave too much homework with no follow-up, and failed to establish a connection between subjects. Some quotes from participants are as follows: P2 "My counselor listened to me and understood me and monitored me, which helped me a lot. Besides, I was getting along well with my classroom teacher, and so I was more engaged in class, and so it worked out for me." P8 "By not getting mad at me because of my mistakes, by telling me to try again and trust myself." P5 "My teacher always made suggestions, gave me the key points of things, which helped me develop study habits."

\subsection{Results of the Eighth Research Question}

The eighth research question was "What factors affect middle school students' study habits?" Table 8 presents the related themes and categories. 
Table 8. Factors affecting study habits

\begin{tabular}{llll}
\hline Theme & Category & & \\
\hline Media & Internet & Spending time on the tablet, texting friends & 4 \\
& Television & Watching TV, series & 3 \\
\multirow{4}{*}{ Environment } & Game & Playing physical or computer games & 2 \\
& Noise & Music, traffic, crowded house & 3 \\
& Clean setting & Spacious space to study & 1 \\
Psychology & Comparison & Parents wanting their kids to be the best, rivalry between friends & 4 \\
& Unwillingness & Sleep, headache, burning eyes, stress & 2 \\
& Pressure & Environmental and family influences & 2 \\
& Career & Going to a good high school, having a good job & 4 \\
\hline
\end{tabular}

Participants" views of factors affecting study habits were grouped under the themes of "media," "environment," and "psychology." The theme of "media" consisted of the categories of Internet $(\mathrm{n}=4)$, television $(\mathrm{n}=3)$, and game $(\mathrm{n}=2)$. The theme of "environment" consisted of the categories of noise $(\mathrm{n}=3)$, clean setting $(\mathrm{n}=1)$, and comparison $(n=4)$. The theme of "psychology" consisted of the categories of unwillingness $(n=2)$, pressure $(n$ $=2)$, and career $(\mathrm{n}=4)$. Some quotes from participants are as follows: P14" For example, bad mood, I feel like nobody understands me. I study little, and I feel like sleeping all the time." P11 "Our will also plays a big role in this. You can't study if you don't feel like studying. Thinking about the future can make you more motivated to adopt study habits." P19 “Time just flies when I'm online, and I just don't feel like studying after I'm done with the Internet."

\section{Discussion}

Participants had a mean QSH score of 3.34, which was moderate. This result is consistent with the literature (Erkan, 1996; Kaya, 2001; Şener, 2001; Ersoy, 2003; Özcan, 2006; Çetin, 2007; Özbey, 2007). The result indicates that middle school students do not know much about adopting study habits because study skills are related to learning readiness and habit acquisition (Yüksel, 2012). Students who prepare themselves to learn and make learning into a habit are more likely to develop study habits. Therefore, students should set learning as a goal and use different techniques to acquire study habits. According to the qualitative results, middle school students see study habits as routines that are necessary to succeed in the future. They think that study habits can make them more determined and help them have good careers in the future. This result suggests that middle school students want to get high grades and do well in the central exam they have to take in eighth grade. Students who graduate from good high schools are more likely to go to good universities. The central exam plays a significant role in their future academic and professional lives and socioeconomic status (Dönmez, 2009; Sarier, 2010).

The results showed no statistically significant difference in study habits between male and female participants, indicating that gender does not affect middle school students' study habits because study habits are mostly shaped by motives and individual perceptions (Warr \& Dowing, 2000). In short, study habits depend on perceptions and motivation rather than gender.

Participants who had appropriate study space had better study habits than those who did not. This result indicates that study space determines study habits because appropriate study space with all the comforts (materials, heat, light, Internet, etc.) make students more likely to enjoy studying and get good grades (Doğanay, Türkoğlu, \& Yıldırım, 2009; Yeşilyaprak, 2019). The qualitative results corroborate this result because participants stated that their study habits were affected most by the Internet, pressure, being compared, television, and noise. Oltulu (2019) also reported that the Internet, family, and home environment affected students' study habits. In other words, external factors distract students. We live in a world where everybody is always online. Adolescents, in particular, spend a great deal of time online streaming, playing video games, and interacting through social media platforms (Kırık, 2013; Ersun, Köze, Muslu, Beytut, Başbakkal, \& Conk, 2012). On the other hand, TV makes children less active, that is, it deprives them of physical activities to get their energy out and to develop cognitive, social, and motor skills (Kalan, 2010; Aral, Ceylan, \& B1çakc1, 2011; Erdoğan, Kesici, \& Şahin, 2011). Being compared with others and pressured into coming out on top causes stress and anxiety. Oltulu (2019), Erdoğan, Kesici and Şahin (2011) found that being compared with others affected students' study habits adversely.

Parents should monitor their children's screen time (TV and Internet), sympathize with them, boost their confidence, share things, and collaborate with them. Participants' study habits did not differ across grade levels, suggesting that grade level does not affect study habits. Yıldız (2014) reported a similar result. However, Güngör 
(2010), Yiğit and Kaçire (2015) found that seven graders had better study habits, while Eren (2011) determined that six graders had better study habits than eight graders. These differences may be due to differences in demographic characteristics, students' attitudes towards study habits, sense of responsibility, and perceptions of the school and future.

Parents had both positive and negative impacts on participants' study habits. Parents provided for them, helped them with their lessons, and served as role models for being hardworking. However, some parents were always "nagging" and pressuring their children into studying more. Home environment and parents' attitudes affect children's development. However, some parents try to influence their children without knowing them and considering their physical, cognitive, and affective development. Parents become too competitive and demanding and put an unwholesome emphasis on winning, resulting in pressure, fear, and feelings of inadequacy in children (Çetin, 2007). Therefore, parents should help their children adopt study habits and assume responsibility for them from an early age without putting pressure on them.

With their interests, attitudes, and actions, teachers are role models for students. They teach their students what to learn and why and how to learn it, and where to use it (Ilgar, 1999; Minasian-Batmanian, Lingard \& Prosser, 2005). Participants stated that teachers had both positive and negative impacts on their study habits. Teachers should listen to their students and support them. However, participants highlighted that teachers left their questions unanswered and did not pay much attention to class. This may be due to teacher-student interaction problems because poor communication is pervasive among teachers.

\section{Recommendations}

Teachers should inform middle school students about study skills and habits. Parents should be offered training in study habits. This study focused on middle school students. Future research should address teachers' views of study habits.

\section{References}

Aral, N., Ceylan, R., \& Yıldız, B. M. (2011). Çocukların televizyon seyretme alışkanlıklarının yaş ve cinsiyete göre incelenmesi. Kastamonu Ë̆itim Dergisi, 19(2), 489-498.

Aristoteles. (2000). Ruh üzerine (Z. Özcan, Çev.). Alfa.

Avcı, Y. (2006). Sinıf içi rehberlik etkinliklerinin öğrencilerin verimli ders çalışma alışsanlıkları üzerindeki etkisi. Yüksek Lisans Tezi, Balıkesir Üniversitesi, Balıkesir.

Bayır, Z. (2015). Üstün zekâlı ögrrencilerin öğrenme stilleri ile ders çalışma alış̧kanlıkları arasındaki ilişkinin çeşitli değişkenler açısından incelenmesi. Yüksek Lisans Tezi, Marmara Üniversitesi, İstanbul.

Çetin, B. (2007). Yeni ilköğretim programı uygulamalarının ilköğretim 4. ve 5. sını öğrencilerinin çalışma alışkanlıkları ile öz-yeterliliklerine etkisi ve öğrencilerin program hakkındaki görüşleri. Doktora Tezi, Marmara Üniversitesi, İstanbul.

Dönmez, B. (2009). Ortaöğretim kurumlarına geçiş sistemine ilişkin bir değerlendirme. Eğitime Bakış Dergisi, $5(15), 11-17$.

Dreeben, O. (2010). Significance of Patient Education for Health Care and Rehabilitation. In O. Dreeben (Ed.), Patient Education in Rehabilitation (pp. 3-8), United Kingdom: Jones and Barlett Learning.

Dural, S. (2008). Sinı öğretmeni adaylarının öğrenme ve ders çalışma stratejileri ile başarıları arasındaki ilişki. Yüksek Lisans Tezi, Adnan Menderes Üniversitesi, Aydın.

Durmuş, H. (2005). Yeter ki iste: Başarılı olma ve verimli ders çalışma yöntemleri. Sim Yayınları.

Erdoğan, A., Kesici, Ş., \& Şahin, İ. (2011). Lise öğrencilerinin başarı güdülerinin ve sosyal kıyaslama düzeylerinin matematik kaygılarını yordaması. Illköğretim Online, 10(2), 646-652.

Eren, O. (2011). Illköğretim 6. 7. ve 8. sinı öğrencilerinin ders çalışma alışkanlıkları ile fen ve teknoloji dersi arasındaki ilişki. Yüksek Lisans Tezi, Ankara Üniversitesi, Ankara.

Erkan, A. (1996). Lise öğrencileri için bir ders çalışma alışkanlıkları envanterinin geliştirilmesi. Yüksek Lisans Tezi, Ege Üniversitesi, İzmir.

Ersoy, S. (2003). İlköğretim 6, 7, 8. sinıf Ingilizce dersindeki başarılarına göre öğrenme stilleri ve çalışma alışkanlıklarının incelenmesi. Yüksek Lisans Tezi, Selçuk Üniversitesi, Konya.

Ersun, A., Şahin Köze, B., Muslu, G., Beytut, D., Başbakkal, Z., \& Conk, Z. (2012). Hemşirelik yüksekokulu öğrencilerinde internet kullanımı ile sosyal destek sistemi arasındaki ilişkinin incelenmesi. İ.Ü.F.N. 
Hemşirelik Dergisi, 20(2), 86-92.

Fullan, M. (2007). The new meaning of educational change (4th ed.). Teachers College Press, Columbia University.

Gettinger, M., \& Seibert, J. K. (2002). Contributions of study skills to academic competence. The School Psychology Review, 31(3), 350-365. https://doi.org/10.1080/02796015.2002.12086160

Güngör, G. (2010). İlköğretim düzeyindeki öğrencilerin benlik kavramlarının ve çalışma alışkanlıklarının değerlendirilmesi. Yüksek Lisans Tezi, Gazi Üniversitesi, Ankara.

İlgar, Ş. (1999). Sınav kaygısı ile verimli ders çalışma tutum ve alışkanlığının karşılaştırılması. 4. ulusal eğitim bilimleri kongresi bildirileri (pp. 109-128). Anadolu Üniversitesi Eğitim Fakültesi Yayınları.

Kalan, Ö. (2010). Medya okuryazarlığı ve okul öncesi çocuk ebeveynlerin medya okuryazarlığı bilinci üzerine bir araştırma. İstanbul Üniversitesi İletişim Fakültesi Dergisi, 1(39), 59-73.

Karasar, N. (2012). Bilimsel araştırma yöntemi. Ankara: Nobel.

Kaya, M. (2001). Lise 1. sınıf öğrencilerine verimli çalışma alışkanlıkları kazandırmada grup rehberliğinin etkisi. Yüksek Lisans Tezi, İnönü Üniversitesi, Malatya.

Kırık, A. M. (2013). Televizyonun gelişim çağı çocukları üzerindeki olumsuz etkileri ve ebeveynlerin kontrol sorunu. 21. Yüzyllda Eğitim ve Toplum, 2(4), 189-198.

Loeserman, A. R., \& Verdaguer, P. (2004). Proust and the discourse on habit. Retrieved Feb. 12, 2019, from https://pdfs.semanticscholar.org/7786/6b14577007654a07ca86ce7b398e8ba0fc3f.pdf

Minasian-Batmanian, L. C., Lingard, J., \& Prosser, M. (2005). Differences in students' perceptions of learning compulsory foundation biochemistry in the health sciences professions. Advances in Health Sciences Education, 10(4), 279-290. https://doi.org/10.1007/s10459-005-1404-7

Oltulu, M. (2019). Ortaokul öğrencilerinin ders çalışma alışkanlıklarının ebeveyn, öğretmen ve öğrenci görüşlerine göre incelenmesi. Yüksek Lisans Tezi, Necmettin Erbakan Üniversitesi, Konya.

Özbey, N. (2007). İlköğretim öğrencilerinin ders çalışma alışkanlıklarının bazı değişkenler açısından incelenmesi. Yüksek Lisans Tezi, Osmangazi Üniversitesi, Eskişehir.

Özcan, G. (2006). İlköğretim dördüncü ve beşinci sınıf öğrencilerinin ders çalışma alışkanlıkları ve ortamlarının incelenmesi. Yüksek Lisans Tezi. Marmara Üniversitesi, İstanbul.

Özsoy, G., Memiş, A., \& Temur, T. (2009). Metacognition study habits and attitudes. International Electronic Journal of Elementary Edocation, 1(2), 279-290.

Patton, M. Q. (2016). Nitel mülakat yapma. In M. Çakır \& S. İrez (Eds.), Nitel Araştırma ve Değerlendirme Yöntemleri (pp. 339-428). Pegem.

Sarıer, Y. (2010). Ortaöğretime giriş sınavları (OKS-SBS) ve PISA sonuçları 1şığında eğitimde firsat eşitliğinin değerlendirilmesi. Ahi Evran Üniversitesi Ĕ̆itim Fakültesi Dergisi, 1(3), 107-129.

Şener, K. (2001). İlköğretim öğrencilerinin çalışma alışkanlıklarının matematikteki başarılarına etkisi. Yüksek Lisans Tezi, Fırat Üniversitesi, Elazı̆̆.

Tan, H. (1996). Verimli ders çalışma ve hayata hazırlanma. Alkım Yayınevi.

Tashakkori, A., \& Creswell, J. (2007). The new era of mixed methods. Journal of Mixed Methods Research, 1(1), 3-8. https://doi.org/10.1177/2345678906293042

Türkoğlu, A., Çengel, M., ve Yılmaz, S. (2006). Ders çalışma ve öğrenme teknikleri. XV. In Ulusal Eğitim Bilimleri Kongresi Bildiri Özetleri Kitapçı̆̆l (pp. 51-52).

Uluğ, F. (2012). Okulda başart. Remzi Kitabevi.

Warr, P., \& Dowing, J. (2000). Learning strategies, learning anxiety and knowledge acquisition. The British Journal of Psychology, 91(3), 311-333. https://doi.org/10.1348/000712600161853

Yenilmez, K., \& Özbey, N. (2007). İlköğretim öğrencilerinin ders çalışma alışkanlıklarının bazı değişkenler açısından incelenmesi. Abant İzet Baysal Üniversitesi Ĕ̆itim Fakültesi Dergisi, 7(2), 1-15.

Yeşilyaprak, B. (2019). 21. yüzyılda eğitimde rehberlik hizmetleri gelişimsel yaklaşım. Nobel.

Yiğit, B., \& Kaçire, İ. (2015). Ortaokul öğrencilerinin ders çalışma alışkanlıklarının incelenmesi. Mustafa Kemal Üniversitesi Sosyal Bilimler Enstitüsü Dergisi, 12(31), 309-319. 
Yıldırım, A., Doğanay, A., \& Türkoğlu, A. (2009). Ders çalı̧̧ma ve öğrenme yöntemleri. Seçkin Yayıncılık.

Yüksel, S. (2012). Öğrenme stratejileri ve sınıflamalar. In S. Fer (Ed.), Öğrenme Öğretme Kuram ve Yaklaşımları (pp. 151-164). Anı Yayıncilık.

\section{Copyrights}

Copyright for this article is retained by the author, with first publication rights granted to the journal.

This is an open-access article distributed under the terms and conditions of the Creative Commons Attribution license (http://creativecommons.org/licenses/by/4.0/). 